\title{
Foreign Direct Investment, Economic Freedom and Economic Growth: Evidence from Developing Countries
}

\author{
Md. Shakib Hossain ${ }^{1}$ \\ ${ }^{1}$ East West University, Bangladesh \\ Correspondence: Md. Shakib Hossain, Senior Lecturer, East West University, Bangladesh. E-mail: \\ shakibbhossain@gmail.com \\ Received: May 19, 2016 \\ Accepted: July 18, 2016 \\ Online Published: October 25, 2016 \\ doi:10.5539/ijef.v8n11p200 \\ URL: http://dx.doi.org/10.5539/ijef.v8n11p200
}

\begin{abstract}
This paper has explores the interplay between economic freedom, foreign direct investment and economic growth using panel data analysis for a sample of 79 developing countries from 1998 to 2014 by considering the level of economic freedom, as provided by the "Heritage Foundation". Panel unit root, pedroni residual co-integration test, generalized least square (GLS), feasible GLS (FGLS), pooled OLS, random effect, fixed effect, poisson regression, prais-winsten, generalized method of movement (GMM) and generalized estimating equation (GEE) methods have used to estimates the relationship. According to the OLS and generalized method of movement the coefficient implies that a one standard deviation improvement in business freedom, trade freedom, size, investment freedom, property rights, freedom from corruption, labor freedom, financial freedom, fiscal freedom, monetary freedom increases FDI by $21.4 \%, 15.6 \%, 21.6 \%, 17.5 \%, 11.55,9.1 \%, 6.9 \%, 8.5 \%$, $7.4 \%, 10.3 \%$ and $56.1 \%, 45.3 \%, 58.3 \%, 51.6 \%, 33.7 \%, 39.2 \%, 47.4 \%, 41.6 \%, 32.5 \%, 38.5 \%$ points respectively and for the economic variable, the coefficient implies that a one standard deviation improvement in GDPG and GDPPC increases FDI by $24.1 \%, 17.4 \%$ and $30.2 \%, 33.4 \%$ points respectively. By using the other method like random effect, fixed effect, poisson regression, prais-winsten and generalized estimating equation (GEE) method explores that economic freedom in the host country is a positive determinants of FDI inflows in developing countries and also the result suggests that foreign direct investment is positively correlated with the economic growth in the host countries.
\end{abstract}

Keywords: economic freedom, foreign direct investment, generalized least square, poisson regression, generalized estimating equation

\section{Introduction}

Various literature have agreed that multinational corporations (MNCs) invest in a specific locations mainly because of the host countries' strong economic fundamentals, such as a large market size, stable macroeconomic environment, availability of skilled labor and infrastructure, that influence the attractiveness of the country to FDI inflows (e.g., Dunning, 1993; Globerman et al., 2003). Because of the transition of the economic phenomena less conventional determinants factors like economic freedom pay close attention for the business and economic researcher. It has been widely acknowledged among growth analysts that a country, which enjoys more economic freedom, tends to attract more FDI inflows and growth faster than country that is being denied enjoying same freedom (e.g., Ayal \& Karras, 1998; Cebula \& Mixon, 2012; Ajide, 2013). Considering the importance of these factors the Heritage Foundation has developed the Economic Freedom Index (EFI) based on these policy parameters. They have included business freedom, investment climate, trade openness, monetary and fiscal environment in the index. Heritage Foundation is defines the Economic Freedom as -aspect of human liberty that is concerned with the material independence of the individual in relation to the state and other prearranged groups. The highest form of economic freedom provides an absolute right of property ownership, fully realized freedoms of movement for labor, capital, and goods, and an absolute absence of coercion or constraint of economic liberty beyond the extent necessary for citizens to protect and maintain liberty itself. The basic purpose of ensuring economic freedom is to promote entrepreneurship and decentralizes and liberalized economic functions and business environment by decelerating government interferences. According to the Adkins et al. (2002) find that the level of economic freedom at the beginning of the growth period does not contribute significantly to explaining growth, but that positive changes in economic freedom do so. Economic 
freedom is a significant positive determinant of FDI. Economic freedom always stimulates foreign direct investment and because of unremitting flow of FDI escalates the economic competitiveness in a developing country. The nature of relationship between FDI and economic growth has been a vast discussed matter in the various amount of economic literature. Different literatures have highlights that there are positive and significant relationship between FDI and growth. Chakrabarti (2001), Asiedu (2002) and Zhao (2013) has pointed out that higher economic growth results in greater FDI inflows as it is a measure of the attractiveness of the host countries. There are still debates on this topic especially for the developing countries. According to Hansen and Rand (2006), the consensus seems to be that of a affirmative relationship between FDI inflows and economic growth in host countries provided the receiving countries have achieved a minimum level of educational, technological, and/or infrastructural development.FDI and economic freedom both are significantly correlated with the economic growth but it is also observed among the different developing countries that the host country requires adequate human capital, economic stability and liberalized markets to benefits from long-term capital flows. In this paper, the basic consideration factor is to observe the relationship among economic freedom, economic growth and FDI in the developing countries by using the Heritage Foundation economic index without considering the conventional factors. The paper has incorporated with the various sections; section 2 literature review, section 3 model specification, section 4 empirical evidence and section 5 conclusion.

\section{Literature Review}

Because of the radical transition of the business and its relevant fields, traditional determinants (wage costs, infrastructure or macroeconomic policy) of FDI is no longer hold rather less traditional determinants have become more important, like institutions or economic freedom. Economic freedom is a significant determinant of foreign direct investment as well as a noteworthy factor in economic growth (e.g., Barro, 1997; Dawson, 1998; Estrin, Bevan, \& Meyer, 2001; Ghura \& Goodwin, 2000; Heckelman, 2000).

Bengoa, Marta, and Sanchez-Robles (2003) have investigated the relationship between economic freedom and foreign direct investment by using panel data of 18 different Latin American countries from the period 1970 to 1999. Empirical results has illustrated that economic freedom facilitated FDI inflow and the economic growth has also found definitely related with FDI.

Many empirical studies have also found that economic freedom exert a major effect on cross-country differences in both per capita income and economic growth (e.g., De Haan et al., 2006; Azman-Saini et al., 2010; Compton et al., 2011).

By using both fixed effects and first -difference GMM estimation, Levina (2011) has investigated the relationship between foreign direct investment, economic freedom and economic growth. According to the GMM estimation of dynamic model has explored that both of the variables foreign direct investment and economic freedom are positively influence on the economic growth.

Gwartney (2009) has penetratingly determined that countries with having enormous amount of economic freedom leads to higher shares of private investment in GDP, higher productivity of private investment, grow more rapidly and achieve higher levels of per capita income than countries with lower levels of economic freedom.

Different factors under the economic freedom index have made a significant consequence on unremitting flow of foreign direct investment. Barro (2000) has indentified that protected and secure property rights accelerate the growth performance not only by stimulating investments, but also by increasing the productivity of investments. Demetriades and Law (2006) have found that inadequate sound financial institutions may not succeed in delivering long-run economic growth in low-income countries.

There are also mixed opinion regarding the relationship among economic freedom, foreign direct investment and economic growth. Using generalized method-of-moment system estimator in 85 different countries Azman-Saini, Baharumshah, and Law (2010) has explored that FDI by itself has no direct (positive) effect on output growth. Instead, the effect of FDI is contingent on the level of economic freedom in the host countries. This means the countries promote greater freedom of economic activities gain significantly from the presence of multinational corporations.

Excluding the economic freedom, there are major considerable elements that make rigorous effects on FDI like, market size (Asiedu, 2006), Mlambo (2006) and Zhang (2013), macroeconomic stability (Onyeiwu \& Shrestha, 2004) and capital stock (Dutta \& Osei-Yeboah, 2010) are the major determinants factors for stimulating FDI in developing countries.

Concentrates on Bengoa and Sanchez-Robles (2003) empirical work that FDI is positively and significantly correlated with economic growth, but host countries should accumulated human capital, economic stability, and 
liberalized markets in order to attain the benefit from long term inflows. Using data on 80 countries for the period 1979-98 Durham (2004) have failed to identify a positive relationship among FDI, economic freedom and economic growth, based on his empirical work he advocated that the effects of are contingent on the "absorptive capability" of host countries.

\section{Model Specification}

This paper is mainly explores the interplay between economic freedom, foreign direct investment (FDI) and economic growth using panel data analysis for a sample of 79 different developing countries from 1998-2014. As part of the methodological design, the basic equation is illustrated below:

$$
\begin{gathered}
F D I=\alpha_{0}+\alpha_{1} G D P P C+\alpha_{2} G D P G+\alpha_{3} \text { Businesss Freedom }+\alpha_{4} \text { Trade Freedom }+\alpha_{5} \text { Government Size }+\alpha_{6} \text { Investment } \\
\text { Freedom }+\alpha_{7} \text { Property Rights }+\alpha_{8} \text { Freedom from Corruption }+\alpha_{9} \text { Labor Freedom }+\alpha_{10} \text { Financiaal Freedom }+ \\
\alpha_{11} \text { Monetory Freedom }+\alpha_{12} \text { Democracy }+\alpha_{13} \text { Political Stability }+e_{t}
\end{gathered}
$$

Where $\alpha_{0}, \alpha_{1-} \alpha_{13}$ are parameters to be estimated.

$e_{t}$ is stochastic error terms assumed to be independently and identically distributed.

For measuring the relationship among economic freedom, foreign direct investment and economic growth different methods have used.

At first panel unit root test have accomplished for estimating whether the data are stationary or not.

\section{Panel Unit Root Test: Levin, Lin and Chu}

Levin, Lin and Chu start panel unit root test by consider the following basic ADF specification.

$$
D Y_{i t}=\alpha Y_{i-1}+\sum_{j=1}^{P i} \beta_{i t} D Y_{i-j}+X_{i t}^{*} \delta+\mathcal{E}_{i t}
$$

Where, $D Y_{i t}=$ difference term of $Y_{i t}$;

$\mathrm{Y}_{\mathrm{it} 1}=$ panel data;

$\alpha=\rho-1$;

$\mathrm{p}_{\mathrm{i}}=$ the number of lag order for difference terms;

$\mathrm{X}_{\mathrm{it}}^{*}=$ exogenous variable in model such as country fixed effects and individual time trend;

$\varepsilon_{\mathrm{it}}=$ the error term of equation 2 .

LLC panel unit root test has null hypothesis as panel data has unit root as well as can present below that:

$\mathrm{H}_{0}$ : null hypothesis as panel data has unit root (assumes common unit root process).

$\mathrm{H}_{1}$ : panel data has not unit root.

\section{Im, Pesaran and Shin}

The properly standardized $t^{*}{ }_{\mathrm{NT}}$ has an asymptotic standard normal distribution and also it was rewritten to be new t-statistics as well as can show below that: (see equation 3).

$$
W_{t^{*} N T}=\sqrt{ } n\left[\left(t_{N T}-N^{-I \sum{ }_{t=1}} E\left(t_{i}{ }_{i T}\left(p_{i}\right)\right)\right)\right] / \sqrt{ }\left(N^{-1} \sum_{i=1}^{n} \operatorname{var}\left(t_{i x}\left(p_{i}\right)\right)\right)
$$

Where, $\mathrm{W}_{\mathrm{t}^{*} \mathrm{NT}}$ is $\mathrm{W}$-statistics has been used to test panel data based on Im, Pesaran and Shin techniques. Also this technique has non-stationary as null hypothesis as well as to show below that:

$\mathrm{H}_{0}$ : null hypothesis as panel data has unit root (assumes individual unit root process).

$\mathrm{H}_{1}$ : panel data has not unit root.

\section{Fisher-Type Test using ADF and PP-Test (Maddala and Wu and Choi )}

Madala and $\mathrm{Wu}$ proposed the use of the Fisher $(\mathrm{P} \lambda)$ test which is based on combining the P-values of the test-statistics for unit root in each cross-sectional unit. Let $p_{i}$ are $U[0,1]$ and independent, and $-2 \log _{\mathrm{e}} p_{\mathrm{i}}$ has a $\chi^{2}$ distribution with $2 \mathrm{~N}$ degree of freedom and can be written in equation 4 .

$$
P \lambda=-2 \sum_{i=1}^{N} \log _{e} p_{i}
$$

Where, $\mathrm{P}_{\lambda}=$ Fisher $\left(\mathrm{P}_{\lambda}\right)$ panel unit root test

$$
\mathrm{N}=\text { all } \mathrm{N} \text { cross-section }
$$

$-2 \sum^{\mathrm{N}}{ }_{\mathrm{i}=1} \log _{\mathrm{e}} \mathrm{p}_{\mathrm{i}}=$ it has a $\chi^{2}$ distribution with $2 \mathrm{~N}$ degree of freedom

In addition, Choi demonstrates that: (see more detail of Choi demonstrates that in equation 5). 


$$
Z=\left(1 / \sqrt{ } N_{i=1}\right)\left[\sum^{N}{ }_{i=1} \theta_{i}^{-1}\left(p_{i}\right)\right]-->N(0,1)
$$

Where, $Z=Z$-statistic panel data unit root test;

$\mathrm{N}=$ all $\mathrm{N}$ cross-section in panel data;

$\Theta_{i}^{-1}=$ the inverse of the standard normal cumulative distribution function;

$\mathrm{p}_{\mathrm{i}}=\mathrm{it}$ is the $\mathrm{P}$-value from the $\mathrm{i}^{\text {th }}$ test.

Both Fisher (P) Chi-square panel unit root test and Choi Z-statistics panel data unit root test have non-stationary as null hypothesis as well as to show below that:

$\mathrm{H}_{0}$ : null hypothesis as panel data has unit root (assumes individual unit root process);

$\mathrm{H}_{1}$ : panel data has not unit root.

\section{Hadri}

The Hadri test for panel data has the hypothesis to be tested is $\mathrm{H}_{0}$ is null hypothesis and $\mathrm{H}_{1}$ is against null hypothesis and can show below that:

$\mathrm{H}_{0}$ : null hypothesis as panel data has not unit root (assumes common unit root process);

$\mathrm{H}_{1}$ : panel data has unit root.

\section{Panel Cointegration Test}

In order to solve the spurious regression problem and violation of the assumptions of the classical regr ession model, cointegration analysis is used to examine the long run relationship between the variables. This test is mainly accomplished for identifying the long run relationship among economic freedom, FD I and economic growth.

$$
Y_{i, t}=\alpha_{1}+\beta_{1 i} x_{1 i, t}+\beta_{2 i} x_{2 i, t}+\ldots .+\beta_{M i} x_{M i, t}+e_{i, t,}, t=1, \ldots . T ; i=1, \ldots . N
$$

Here, $\mathrm{Y}$ indicates the dependent variable like FDI and $\mathrm{X}_{1}$ to $\mathrm{X}_{\mathrm{m}}$ indicates the different independent variables. (See in details Table 2).

Another method have used that is known as a Kao for estimating the long run relationship between the variables. Kao have used both DF and ADF to test for co-integration in panel as well as this test similar to the standard approach adopted in the EG-step procedures. Also this test start with the panel regression model as set out in equation 7 .

$$
Y_{i t}=X_{i t} \beta_{i t}+Z_{i t} \gamma_{0}+\varepsilon_{i t}
$$

Where $\mathrm{Y}$ and $\mathrm{X}$ are presumed to be non-stationary and: (see equation 8 )

$$
{\hat{e_{i t}}}_{i}=\rho{\hat{e_{i t}}}+V_{i t}
$$

where $\hat{e}_{i t}=\left(Y_{i t}-X_{i t} \hat{\beta}_{i t}-Z_{i t} \hat{y}\right)$ are the residuals from estimating equation 8 . To test the null hypothesis of no co-integration amounts to test $\mathrm{H}_{0}: \rho=1$ in equation 8 against the alternative that $\mathrm{Y}$ and $\mathrm{X}$ are co-integrated (i,e., $\left.\mathrm{H}_{1}: \rho<1\right)$.

Considering the demand of the paper when $\Omega$ is known, $\beta$ is efficiently estimated with generalized least squares (GLS).

$$
\hat{\beta}_{G L S}=\left(X^{\prime} \hat{\Omega}^{-1} X\right)^{-1} X^{\prime} \hat{\Omega}^{-1} y
$$

Instead of assuming the structure of heteroskedasticity, the work may estimate the structure of heteroskedasticity from OLS. First, estimate $\widehat{\Omega}$ from OLS and, second, use $\widehat{\Omega}$ instead of $\Omega$.

$$
\hat{\beta}_{F G L S}=\left(X^{\prime} \hat{\Omega}^{-1} X\right)^{-1} X^{\prime} \hat{\Omega}^{-1} y
$$

After GLS and FGLS the paper has also tested OLS. A standard panel OLS estimator for the coefficient $\beta_{\mathrm{i}}$ given by:

$$
\hat{\beta}_{i, \text { OLS }}=\left[\sum_{i=1}^{N} \sum_{t=1}^{T}\left(X_{i t}-X_{i}^{*}\right)^{2}\right]^{-1} \sum_{i=1}^{N} \sum_{t=1}^{T}\left(X_{i t}-X_{i}^{*}\right)\left(Y_{i t}-Y_{i}^{*}\right)
$$

Where

$\mathrm{i}=$ cross-section data and $\mathrm{N}$ is the number of cross-section;

$\mathrm{t}=$ time series data and $\mathrm{T}$ is the number of time series data;

$\beta_{\mathrm{i} \text { OLS }}=$ a standard panel OLS estimator;

$\mathrm{X}_{\mathrm{it}}=$ exogenous variable in model; 


$$
\begin{aligned}
& \mathrm{X}_{\mathrm{i}}^{*}=\text { average of } \mathrm{X}_{\mathrm{I}}^{*} ; \\
& \mathrm{Y}_{\mathrm{it}}=\text { endogenous variable in model; } \\
& \mathrm{Y}_{\mathrm{i}}^{*}=\text { average of } \mathrm{Y}^{*} \text {. }
\end{aligned}
$$

The most commonly used models in panel data analysis are fixed effects (FE) and random effects (RE) regressors in linear regression using ordinary least squares (OLS).

Here in this paper the fixed effects model is used binary variables. So the equation for the fixed effects model becomes:

$$
Y_{i t}=\beta_{0}+\beta_{1} X_{1, i t}+\ldots+\beta_{k} X_{k, i t}+\gamma_{2} E_{2}+\ldots+\gamma_{n} E_{n}+u_{i t}
$$

Where, $\mathrm{Y}_{\mathrm{it}}=$ is the dependent variable (DV) is FDI where $\mathrm{i}=$ entity and $\mathrm{t}=$ time.

$X_{\mathrm{k}, \mathrm{it}}=$ represents independent variables ( See in details in Table 2).

$\beta_{\mathrm{k}}=$ is the coefficient for the IVs.

$\mathrm{u}_{\mathrm{it}}=$ is the error term.

$\mathrm{E}_{\mathrm{n}}=$ is the entity $\mathrm{n}$.

$\gamma_{2}=$ is the coefficient for the binary repressors (entities).

The random effects model is:

$$
Y_{i t}=\beta X_{i t}+\alpha+u_{i t}+\varepsilon_{i t}
$$

In Poisson regression, the paper supposes that the Poisson incidence rate $\boldsymbol{\mu}$ is determined by a set of $\mathrm{k}$ regressor variables (the X's). The expression relating these quantities is $\mu$.

$$
\boldsymbol{\mu}=t \exp \left(\beta_{1} X_{1}+\beta_{2} X_{2}+\ldots \ldots+\beta_{K} X_{K}\right)
$$

$X_{1 \equiv 1}$ and $\beta_{1}$ is called the intercept. The regression coefficients $\beta_{1}, \beta_{2, \ldots .} \beta_{\mathrm{k}}$ are unknown parameters that are estimated from a set of data. Their estimates are labeled $b_{1}, b_{2} \ldots b_{k}$.

Using this notation, the fundamental Poisson regression model for an observation $\mathrm{i}$ is written as

$$
P_{r}\left(Y_{i}=y_{i} \mid \mu_{i} t_{i}\right)=\frac{e^{-\mu_{1} t_{l}}\left(\mu_{i} t_{i}\right)^{y_{1}}}{Y_{i} !}
$$

Where, $\boldsymbol{\mu}_{\mathrm{i}}=\mathrm{t}_{\mathrm{i}} \boldsymbol{\mu}\left(\dot{\mathrm{X}}_{\mathrm{i}} \beta\right)=\mathrm{t}_{\mathrm{i}} \exp \left(\beta_{1} \mathrm{X}_{1 \mathrm{i}}+\beta_{2} \mathrm{X}_{2 \mathrm{i}}+\ldots \ldots+\beta_{\mathrm{K}} \mathrm{X}_{\mathrm{Ki}}\right)$

That is, for a given set of values of the regressor variables, the outcome follows the Poisson distribution.

In the Prais-Winsten the equation is:

$$
Y_{t}=\alpha+X_{t} \beta+\varepsilon_{t}
$$

Where $Y_{t}$ is the time series of interest at time, $\beta$ is a vector of coefficients, $X_{t}$ is a matrix of explanatory variables and $\varepsilon_{\mathrm{t}}$ error terms. The error terms can be serially correlated over time $\varepsilon_{\mathrm{t}}=\mathrm{p} \varepsilon_{\mathrm{t}-1}+\mathrm{e}_{\mathrm{t}},|\mathrm{p}|<1$ and $\mathrm{e}_{\mathrm{t}}$ is a white noise. In the Generalized Method of Moments estimator based on these population moments conditions is the value of $\theta$ that minimizes.

$$
Q_{n}(\theta)=\left\{n^{-1} \sum_{t=1}^{n} f\left(v_{t}, \theta\right)^{\prime}\right\} W_{n}\left\{n^{-l} \sum_{t=1}^{n} f\left(v_{t}, \theta\right)\right\}
$$

Where $\mathrm{W}_{\mathrm{n}}$ is a non-negative definite matrix that usually depends on the data but converges to a constant positive definite matrix as $\mathrm{n} \longrightarrow \infty$.

The GEE approach estimates $\beta$ by solving the estimating equations (Liang and Zeger), and (Prentice):

$$
\sum_{i=1}^{N} D^{\prime}{ }_{i} V_{i}^{-1}\left(Y_{i}-\mu_{i}\right)=0
$$

Where $D_{i}=D_{i}(\beta)=\partial \mu_{i}(\beta) / \partial \beta^{\prime}$, and $V_{i}$ is the working covariance matrix of $Y_{i} \cdot V_{i}$ can be expressed in terms of a correlation matrix $R(\alpha): \mathrm{V}_{\mathrm{i}}=\mathrm{A}_{\mathrm{i}}^{1 / 2} \mathrm{R}(\alpha) \mathrm{A}_{\mathrm{i}}^{1 / 2}$ where $\mathrm{A}_{\mathrm{i}}$ is a diagonal matrix with elements $\operatorname{var}\left(\mathrm{Y}_{\mathrm{it}}\right)=\mathrm{V}\left(\mu_{\mathrm{it}}\right)$, specified as functions of the means $\mu_{\mathrm{it}} \alpha$ is some unknown parameter.

\subsection{Data Sources}

This article has employed panel data for 79 countries over the period from 1998 to 2014 among different developing countries (See in Table 1). FDI which is noted as an dependent variable is measured in current U.S. dollars divided by the host country's total population as the dependent variable, and data come from UNCTAD. 
Data on FDI are provided by several sources, such as Balance of Payments Statistics Yearbook and International Finance Statistics by the International Monetary Fund (IMF), European Union Direct Investment Yearbook by EUROSTAT, World Investment Report by UNCTAD, World Development Indicators by the World Bank, and International Direct Investment Statistics Yearbook by OECD. Only the UNCTAD, OECD, and EUROSTAT offer a sectoral breakdown of FDI flows and stocks. The drawback is that OECD and EUROSTAT only cover a very limited number of world countries and thus the total direct investment received by any given country cannot be completely assessed. Moreover, the paper is more interested in FDI inflows than FDI stocks because policy recommendations are usually formulated to boost FDI inflows rather than to accumulate FDI stocks for a given period. However, only UNCTAD provides a break down into two different categories: FDI figures for developed and for developing countries that really serve our purpose. Because of making contemplative judgment FDI related data from accumulated from the UNCTAD.

Table 1. List of the countries

Afghanistan, Albania, Algeria, Angola, Argentina, Armenia, Azerbaijan, Bangladesh, Belarus, Benin, Bhutan, Bolivia, Botswana, Bulgaria, Burundi, Cambodia, Chad, Colombia, Comoros, Cuba, Dominica, Ecuador, El Salvador, Ethiopia, Figgie, Gambia, Georgia, Ghana, Grenada, Guatemala, Guinea, Guyana, Haiti, Honduras, Iran, Iraq, Jamaica, Jordan, Kazakhstan, Kenya, Kosovo, Lebanon, Liberia, Libya, Madagascar, Maldives, Mali, Moldova, Mongolia, Morocco, Mozambique, Myanmar, Namibia, Nepal, Nicaragua, Nigeria, Pakistan, Papua New Guinea, Peru, Senegal, Serbia, Sierra Leone, Somalia, South Sudan, Sri Lanka, Sudan, Suriname, Tajikistan, Timor-Leste, Togo, Tonga, Tunisia, Uganda, Ukraine, Venezuela, Vietnam, Yemen, Zambia and Zimbabwe.

Here in this study the paper has applied the Index of Economic Freedom provided by Heritage Foundation, for measuring economic freedom that included 50 independent variables which fall into 10 categories of economic freedom. Each country receives its overall economic freedom score based on the simple average of the 10 individual factor score. Each factor has a unique scale that runs from 1 to 5 , where a score of 1 indicates an economic environment that are most conducive to economic freedom and a score of 5 indicates the opposite. For the economic growth the proxy variables are GDPPG and GDPG, the data are accumulated from the World Development Indicators, 2014. The other control variable democracy, the data are accumulated from the Quality of Government Institute, 204, here the index value range from 0 ( $0=$ represent no democracy) to 100 (100 represent full democracy). Another control variable is political stability; the data are aggregating from the worldwide governance indicators. For the political stability the data collection method and research methodology all the things can be access in that particular website: www.govindicators.org.

Table 2. Description of the variables

\begin{tabular}{|c|c|c|c|c|}
\hline Variables & & Description & Source & Expected Sign \\
\hline \multirow[t]{5}{*}{$\begin{array}{l}\text { Dependent } \\
\text { Variables }\end{array}$} & $\begin{array}{l}\text { Foreign Direct } \\
\text { Investment }\end{array}$ & $\begin{array}{l}\text { Total FDI inflows a host country receives at time } t \text { divided by } \\
\text { the host country's total population (i.e., FDI per capita) }\end{array}$ & UNCTAD,2014 & $(+)$ \\
\hline & $\begin{array}{l}\text { Political Stability } \\
\text { (PS) and absence of } \\
\text { violence }\end{array}$ & $\begin{array}{l}\text { Perception of likelihood that the government in power will be } \\
\text { destabilized or overthrown by possibly unconstitutional } \\
\text { and/or violent means, including domestic violence and } \\
\text { terrorism. }\end{array}$ & $\begin{array}{l}\text { Worlds governance } \\
\text { Indicator, } 2014\end{array}$ & $(+)$ \\
\hline & $\begin{array}{l}\text { Government } \\
\text { Effectiveness }\end{array}$ & $\begin{array}{l}\text { The quality of public services, the quality of the civil service } \\
\text { and the degree of its independence from political pressures, } \\
\text { the quality of policy formulation and implementation, and the } \\
\text { credibility of the government's commitment to such policies. }\end{array}$ & $\begin{array}{l}\text { Worlds governance } \\
\text { Indicator, } 2014\end{array}$ & $(+)$ \\
\hline & Regulatory Quality & $\begin{array}{l}\text { The ability of the government to formulate and implement } \\
\text { sound policies and regulations that permits and promotes } \\
\text { private sector development. }\end{array}$ & $\begin{array}{l}\text { Worlds governance } \\
\text { Indicator, } 2014\end{array}$ & $(+)$ \\
\hline & Rule of Law (RL) & $\begin{array}{l}\text { The extent to which agents have confidence in and abide by } \\
\text { the rules of society, and in particular the quality of contract } \\
\text { enforcement, the police, and the courts, as well as the } \\
\text { likelihood of crime and violence. }\end{array}$ & $\begin{array}{l}\text { Worlds governance } \\
\text { Indicator, } 2014\end{array}$ & $(+)$ \\
\hline $\begin{array}{l}\text { Independent } \\
\text { Variables }\end{array}$ & $\begin{array}{l}\text { Control of } \\
\text { Corruption }\end{array}$ & $\begin{array}{l}\text { The extent to which public power is exercised for private } \\
\text { gain, including both petty and grand forms of corruption, as } \\
\text { well as "capture" of the state by elites and private interests. }\end{array}$ & $\begin{array}{l}\text { Worlds governance } \\
\text { Indicator, } 2014\end{array}$ & $(+)$ \\
\hline
\end{tabular}




\begin{tabular}{|c|c|c|c|}
\hline Business Freedom & $\begin{array}{l}\text { The ability to generate, operates, and closes up an enterprise } \\
\text { quickly and easily. }\end{array}$ & $\begin{array}{l}\text { Heritage Foundation, } \\
\qquad 2014\end{array}$ & $(+)$ \\
\hline Trade Freedom & $\begin{array}{l}\text { Trade freedom is measuring in the absence of tariff and } \\
\text { non-tariff barriers that influence on imports and exports of } \\
\text { goods and services. }\end{array}$ & $\begin{array}{l}\text { Heritage Foundation, } \\
\qquad 2014\end{array}$ & $(+)$ \\
\hline Government Size & $\begin{array}{l}\text { All government expenditures, including consumption and } \\
\text { transfers. }\end{array}$ & $\begin{array}{l}\text { Heritage Foundation, } \\
\qquad 2014\end{array}$ & $(+)$ \\
\hline Investment Freedom & An assessment of the free flow of capital. & $\begin{array}{l}\text { Heritage Foundation, } \\
\qquad 2014\end{array}$ & $(+)$ \\
\hline Property Rights & $\begin{array}{l}\text { An assessment of the aptitude of individuals to accumulate } \\
\text { private property, protected by clear laws that are fully } \\
\text { compulsory by the state. }\end{array}$ & $\begin{array}{l}\text { Heritage Foundation, } \\
\qquad 2014\end{array}$ & $(+)$ \\
\hline $\begin{array}{l}\text { Freedom from } \\
\text { Corruption }\end{array}$ & $\begin{array}{l}\text { Quantitative data that evaluate the perception of corruption in } \\
\text { the business environment, including levels of governmental } \\
\text { legal, judicial, and administrative corruption. }\end{array}$ & $\begin{array}{l}\text { Heritage Foundation, } \\
\qquad 2014\end{array}$ & $(+)$ \\
\hline Labour Freedom & $\begin{array}{l}\text { It is a composite measure of the aptitude of workers and } \\
\text { businesses to interact without restriction by the state. }\end{array}$ & $\begin{array}{l}\text { Heritage Foundation, } \\
\qquad 2014\end{array}$ & $(+)$ \\
\hline Financial Freedom & $\begin{array}{l}\text { Financial freedom that measure of banking security as well as } \\
\text { independence from government control; state ownership of } \\
\text { banks and other financial institutions. }\end{array}$ & $\begin{array}{l}\text { Heritage Foundation, } \\
\qquad 2014\end{array}$ & $(+)$ \\
\hline Fiscal Freedom & $\begin{array}{l}\text { Fiscal freedom is a measure of the burden of government } \\
\text { from the revenue side and it includes both the tax burden in } \\
\text { terms of the top tax rate on income and the overall amount of } \\
\text { tax revenue as a portion of GDP. }\end{array}$ & $\begin{array}{l}\text { Heritage Foundation, } \\
\qquad 2014\end{array}$ & $(+)$ \\
\hline Monetary Freedom & $\begin{array}{l}\text { Monetary freedom combines a measure of price stability with } \\
\text { an assessment of price controls. }\end{array}$ & $\begin{array}{l}\text { Heritage Foundation, } \\
\qquad 2014\end{array}$ & $(+)$ \\
\hline Democracy & $\begin{array}{l}\text { Index of Democratization. Index that could vary from } 0 \text { (no } \\
\text { democracy) to } 100 \text { (full democracy). }\end{array}$ & $\begin{array}{l}\text { Quality of } \\
\text { Government Institute }\end{array}$ & $(+)$ \\
\hline
\end{tabular}

\section{Empirical Evidence}

Concentrates on the model specification the following table interprets whether the panel data are stationary or not. For identifying this, five different panel unit test is being accomplished (Levin, Lin, \& Chu; Breitung, Im, Pesaran, \& Shin), Fisher-Type test using ADF and PP-test (Maddala, Wu, \& Choi) and Hadri.

Table 3. Panel unit root test

\begin{tabular}{|c|c|c|c|c|c|}
\hline Variables & $\begin{array}{l}\text { Levin Lin and Chu-t } \\
\text { test Values** and prob }\end{array}$ & $\begin{array}{l}\text { Im, Pesaran and Shin W-stat } \\
\text { test Values** and Prob }\end{array}$ & $\begin{array}{l}\text { ADF-Fisher Chi-square } \\
\text { Test Values** and Prob }\end{array}$ & $\begin{array}{l}\text { PP-Fisher Chi-square } \\
\text { Test Values**and Prob }\end{array}$ & Hadri \\
\hline Foreign & -2.94310 & -5.68401 & 15.29884 & 26.32540 & 2.38723 \\
\hline Investment & $\mathrm{P}=0.2905$ & $\mathrm{P}=0.1726$ & $\mathrm{P}=0.0894$ & $\mathrm{P}=0.1421$ & $\mathrm{P}=0.0000$ \\
\hline \multirow[t]{2}{*}{ Business Freedom } & -5.43193 & -3.29851 & 21.14332 & 15.16883 & 4.27094 \\
\hline & $\mathrm{P}=0.0711$ & $\mathrm{P}=-3.29851$ & $\mathrm{P}=21.14332$ & $\mathrm{P}=15.16883$ & $\mathrm{P}=0.0000$ \\
\hline \multirow[t]{2}{*}{ Trade Freedom } & -5.42163 & -8.13416 & 34.28928 & 14.72116 & 3.29842 \\
\hline & $\mathrm{P}=0.0429$ & $\mathrm{P}=0.2805$ & $\mathrm{P}=0.0549$ & $\mathrm{P}=0.1304$ & $\mathrm{P}=0.0000$ \\
\hline \multirow[t]{2}{*}{ Government Size } & -4.92163 & -8.24631 & 23.15993 & 37.12046 & 2.34173 \\
\hline & $\mathrm{P}=0.0672$ & $\mathrm{P}=0.2137$ & $\mathrm{P}=0.0942$ & $\mathrm{P}=0.1786$ & $\mathrm{P}=0.0000$ \\
\hline \multirow[t]{2}{*}{ Investment Freedom } & -7.29884 & -19.76118 & 22.14729 & 15.27661 & 2.18992 \\
\hline & $\mathrm{P}=0.0672$ & $\mathrm{P}=0.1763$ & $\mathrm{P}=0.0549$ & $\mathrm{P}=0.1115$ & $\mathrm{P}=0.0000$ \\
\hline \multirow[t]{2}{*}{ Property Rights } & -4.94116 & -16.29474 & 29.18034 & 17.72383 & 5.46882 \\
\hline & $\mathrm{P}=0.0728$ & $\mathrm{P}=0.0672$ & $\mathrm{P}=0.1529$ & $\mathrm{P}=0.2783$ & $\mathrm{P}=0.0000$ \\
\hline Freedom & -7.34731 & -5.63189 & 27.16720 & 17.17883 & 4.18441 \\
\hline Corruption & $\mathrm{P}=0.0722$ & $\mathrm{P}=0.2673$ & $\mathrm{P}=0.1549$ & $\mathrm{P}=0.2618$ & $\mathrm{P}=0.0000$ \\
\hline \multirow[t]{2}{*}{ Labor Freedom } & -3.29551 & -24.16726 & 28.94825 & 34.12772 & 4.77009 \\
\hline & $\mathrm{P}=0.0826$ & $\mathrm{P}=0.3981$ & $\mathrm{P}=0.1642$ & $\mathrm{P}=0.0549$ & $\mathrm{P}=0.0000$ \\
\hline \multirow[t]{2}{*}{ Financial Freedom } & -6.15484 & -12.63180 & 22.15827 & 32.25331 & 3.68294 \\
\hline & $\mathrm{P}=0.0621$ & $\mathrm{P}=0.2198$ & $\mathrm{P}=0.1219$ & $\mathrm{P}=0.0622$ & $\mathrm{P}=0.0000$ \\
\hline
\end{tabular}




\begin{tabular}{llllll}
\hline Fiscal Freedom & -7.24409 & -18.54220 & 34.65319 & 21.18742 & 3.68294 \\
& $\mathrm{P}=0.0754$ & $\mathrm{P}=0.2093$ & $\mathrm{P}=0.1732$ & $\mathrm{P}=0.1218$ & $\mathrm{P}=0.0000$ \\
Monetary Freedom & -4.21774 & -10.56821 & 27.92454 & 31.66734 & 4.6073 \\
& $\mathrm{P}=0.0421$ & $\mathrm{P}=0.1204$ & $\mathrm{P}=0.1572$ & $\mathrm{P}=0.1925$ & $\mathrm{P}=0.0000$ \\
GDPG & -4.36893 & -9.14553 & 32.40931 & 22.15864 & 2.94182 \\
& $\mathrm{P}=0.0544$ & $\mathrm{P}=0.1120$ & $\mathrm{P}=0.1721$ & $\mathrm{P}=0.2892$ & $\mathrm{P}=0.0000$ \\
GDPPC & -8.42996 & -10.43194 & 27.00781 & 36.42157 & 4.86198 \\
& $\mathrm{P}=0.0490$ & $\mathrm{P}=0.2792$ & $\mathrm{P}=0.1128$ & $\mathrm{P}=0.2459$ & $\mathrm{P}=0.0000$ \\
Democracy & -5.54289 & -11.29095 & 31.43461 & 45.29661 & 4.25186 \\
& $\mathrm{P}=0.0572$ & $\mathrm{P}=0.0729$ & $\mathrm{P}=0.1928$ & $\mathrm{P}=0.2463$ & $\mathrm{P}=0.0000$ \\
Political Stability & -6.22498 & -16.85721 & 26.93173 & 41.47842 & 3.48325 \\
& $\mathrm{P}=0.0386$ & $\mathrm{P}=0.0389$ & $\mathrm{P}=0.2519$ & $\mathrm{P}=0.3146$ & $\mathrm{P}=0.0000$ \\
\hline
\end{tabular}

Source: Own Calculation..

Base on the five different type of panel unit root test such as Levin, Lin and Chu, Im, Pesaran and Shin, Fisher-Type test using ADF and PP-test (Maddala, Wu, \& Choi, 2001) and Hadri methods the variables are not stationary at a level. Now let's see at first difference the data are stationary or not.

From the Table 4 concentrates on the five different type of panel unit root test such as Levin, Lin and Chu, Im, Pesaran and Shin, Fisher-Type test using ADF and PP-test (Maddala, Wu, \& Choi) and Hadri methods the variables are stationary at a first differences.

Table 4. Panel unit root test

\begin{tabular}{|c|c|c|c|c|c|}
\hline Variables & $\begin{array}{c}\text { Levin Lin and Chu-t } \\
\text { test Values** and } \\
\text { prob }\end{array}$ & $\begin{array}{c}\text { Im, Pesaran and Shin } \\
\text { W-stat test Values** } \\
\text { and Prob }\end{array}$ & $\begin{array}{c}\text { ADF-Fisher } \\
\text { Chi-square Test } \\
\text { Values** and Prob }\end{array}$ & $\begin{array}{c}\text { PP-Fisher Chi-square } \\
\text { Test Values**and } \\
\text { Prob } \\
\end{array}$ & Hadri \\
\hline Foreign Direct & -8.32117 & -4.27992 & 21.45184 & 31.68214 & 0.73119 \\
\hline Investment & $\mathrm{P}=0.0000$ & $\mathrm{P}=0.0001$ & $\mathrm{P}=0.0000$ & $\mathrm{P}=0.0007$ & $\mathrm{P}=0.2984$ \\
\hline \multirow[t]{2}{*}{ Business Freedom } & -5.46109 & -6.75941 & 34.18094 & 37.65902 & 0.82532 \\
\hline & $\mathrm{p}=0.0003$ & $\mathrm{P}=0.0005$ & $\mathrm{P}=0.0019$ & $\mathrm{P}=0.0054$ & $\mathrm{P}=0.2137$ \\
\hline \multirow[t]{2}{*}{ Trade Freedom } & -3.11729 & -5.16193 & 32.29031 & 41.11294 & 0.79091 \\
\hline & $\mathrm{P}=0.0004$ & $\mathrm{P}=0.0003$ & $\mathrm{P}=0.0011$ & $\mathrm{P}=0.0018$ & $\mathrm{P}=0.1984$ \\
\hline \multirow[t]{2}{*}{ Government Size } & -2.90318 & -8.22249 & 16.27831 & 24.27943 & 0.68836 \\
\hline & $\mathrm{P}=0.0002$ & $\mathrm{P}=0.0009$ & $\mathrm{P}=0.0034$ & $\mathrm{P}=0.0057$ & $\mathrm{P}=0.3106$ \\
\hline \multirow[t]{2}{*}{ Investment Freedom } & -3.44841 & -6.74209 & 21.0915 & 31.67093 & 0.74167 \\
\hline & $\mathrm{P}=0.0003$ & $\mathrm{P}=0.0009$ & $\mathrm{P}=0.0041$ & $\mathrm{P}=0.0069$ & $\mathrm{P}=0.2492$ \\
\hline \multirow[t]{2}{*}{ Property Rights } & -4.19631 & -8.46318 & 24.29086 & 31.52981 & 0.81670 \\
\hline & $\mathrm{P}=0.0002$ & $\mathrm{P}=0.0011$ & $\mathrm{P}=0.0029$ & $\mathrm{P}=0.0045$ & $\mathrm{P}=0.2781$ \\
\hline Freedom From & -8.17031 & -11.78109 & 36.42156 & 41.26193 & 0.54193 \\
\hline Corruption & $\mathrm{P}=0.0006$ & $\mathrm{P}=0.0018$ & $\mathrm{P}=0.0059$ & $\mathrm{P}=0.0077$ & $\mathrm{P}=0.2094$ \\
\hline \multirow[t]{2}{*}{ Labor Freedom } & -7.21093 & -11.54194 & 25.60912 & 37.55190 & 0.51861 \\
\hline & $\mathrm{P}=0.0007$ & $\mathrm{P}=0.0013$ & $\mathrm{P}=0.0061$ & $\mathrm{P}=0.0082$ & $\mathrm{P}=0.2894$ \\
\hline \multirow[t]{2}{*}{ Financial Freedom } & -5.42885 & -9.39081 & 21.44093 & 38.54817 & 0.61204 \\
\hline & $\mathrm{P}=0.0006$ & $\mathrm{P}=0.0011$ & $\mathrm{P}=0.0062$ & $\mathrm{P}=0.0081$ & $\mathrm{P}=0.1834$ \\
\hline \multirow[t]{2}{*}{ Fiscal Freedom } & -3.40092 & -7.22807 & 18.41063 & 25.49860 & 0.63428 \\
\hline & $\mathrm{P}=0.0004$ & $\mathrm{P}=0.0017$ & $\mathrm{P}=0.0061$ & $\mathrm{P}=0.0079$ & $\mathrm{P}=0.2317$ \\
\hline \multirow[t]{2}{*}{ Monetary Freedom } & -6.16425 & -9.21094 & 19.54831 & 36.48093 & 0.67041 \\
\hline & $\mathrm{P}=0.0004$ & $\mathrm{P}=0.0009$ & $\mathrm{P}=0.0025$ & $\mathrm{P}=0.0063$ & $\mathrm{P}=0.3572$ \\
\hline \multirow[t]{2}{*}{ GDPG } & -6.79162 & -5.42174 & 22.72941 & 34.16809 & 0.72194 \\
\hline & $\mathrm{P}=0.0017$ & $\mathrm{P}=0.0011$ & $\mathrm{P}=0.0025$ & $\mathrm{P}=0.0036$ & $\mathrm{P}=0.1572$ \\
\hline \multirow[t]{2}{*}{ GDPPC } & -5.29842 & -3.19842 & 24.36119 & 38.18442 & 0.86519 \\
\hline & $\mathrm{P}=0.0006$ & $\mathrm{P}=0.0029$ & $\mathrm{P}=0.0005$ & $\mathrm{P}=0.0011$ & $\mathrm{P}=0.2285$ \\
\hline \multirow[t]{2}{*}{ Democracy } & -5.28462 & -8.34992 & 22.49821 & 34.15382 & 0.54926 \\
\hline & $\mathrm{P}=0.0003$ & $\mathrm{P}=0.0007$ & $\mathrm{P}=0.0021$ & $\mathrm{P}=0.0054$ & $\mathrm{P}=0.1492$ \\
\hline \multirow[t]{2}{*}{ Political Stability } & -3.65182 & -6.75672 & 27.29841 & 32.15909 & 0.72194 \\
\hline & $\mathrm{P}=0.0003$ & $\mathrm{P}=0.0008$ & $\mathrm{P}=0.0035$ & $\mathrm{P}=0.0068$ & $\mathrm{P}=0.2908$ \\
\hline
\end{tabular}


To solve the spurious regression problem and violation of the assumptions of the classical regression model, cointegration analysis has used to examine the long run relationship between the variables.

Table 5. Pedroni residual co-integration test

\begin{tabular}{cccc}
\hline & \multicolumn{3}{c}{ Pedroni Residual Co-integration Test } \\
\hline Test Method & No deterministic trend & Deterministic intercept and trend & No deterministic intercept or trend \\
\hline Panel v-statistic & -0.046175 & -1.941032 & -0.158296 \\
& $\mathrm{P}=0.3894$ & $\mathrm{P}=0.3017$ & $\mathrm{P}=0.2984$ \\
Panel rho-Statistic & -1.371829 & 2.821081 & -0.290844 \\
& $\mathrm{P}=0.2112$ & $\mathrm{P}=0.2219$ & $\mathrm{P}=0.1542$ \\
Panel PP-Statistic & -3.541982 & -1.251103 & -2.158239 \\
& $\mathrm{P}=0.0019$ & $\mathrm{P}=0.1427$ & $\mathrm{P}=0.0053$ \\
Panel ADF-Statistic & -2.331904 & -0.541027 & 4.360874 \\
& $\mathrm{P}=0.0011$ & $\mathrm{P}=0.2304$ & $\mathrm{P}=0.0049$ \\
Group rho-Statistic & 0.251882 & 2.019973 & 2.360952 \\
& $\mathrm{P}=0.5417$ & $\mathrm{P}=0.3109$ & $\mathrm{P}=0.2984$ \\
Group PP-Statistic & -3.114562 & -3.560319 & -4.501804 \\
& $\mathrm{P}=0.0003$ & $\mathrm{P}=0.0004$ & $\mathrm{P}=0.0007$ \\
Group ADF-Statistic & -4.031802 & -2.221066 & -2.411206 \\
& $\mathrm{P}=0.0004$ & $\mathrm{P}=0.0037$ & $\mathrm{P}=0.0033$ \\
\hline
\end{tabular}

Source: Own Calculation.

From the no deterministic trends there are 7 different and separate outcomes. Out of 7 outcomes, 3 outcomes interprets that accept the null hypothesis $\left(\mathrm{H}_{0}=\right.$ No cointegration), because the $\mathrm{p}$ value is $>5$. On the other hand 4 outcomes illustrates that reject the null hypothesis and accept the alternative hypothesis. Therefore it is to be noted that base on the no deterministic trend elucidate that the variables are cointegrate. On the other hand from the deterministic intercept and trends have 7 outcomes, out of 7 outcomes 5 outcomes interprets that accept the null hypothesis $\left(\mathrm{H}_{0}=\right.$ No cointegration), because the $\mathrm{p}$ value is $>5$. On the other hand 2 outcomes illustrates that reject the null hypothesis, it means that accept the alternative hypothesis. Therefore it is to be noted that base on the deterministic intercept and trend elucidates that the variables are not cointegrate. According to the no deterministic intercept and trends, out of 7 outcomes 4 outcomes interprets that reject the null hypothesis $\left(\mathrm{H}_{0}=\right.$ No cointegration), because the $\mathrm{p}$ value is $<5$. On the other hand 3 outcomes illustrates that accept the null hypothesis, it means that reject the alternative hypothesis. Therefore it is to be noted that base on the no deterministic intercept and trend method elucidates that the variables are cointegrated. Two trends out of three trends of the Pedroni Residual Cointegration test the variables are cointegrate. Another lucid method (Kao Residual Cointegration) has used to find out the cointegration regarding the variables. From the Table 6 it exhibits that the $\mathrm{p}$ value is less than $5 \%$, means that reject the null hypothesis $\left(\mathrm{H}_{0=}\right.$ No cointegration).

Table 6. Kao residual co-integration test

\begin{tabular}{lll}
\hline ADF & t-Statistic & Prob. \\
\hline & -3.291844 & 0.0028 \\
Residual variance & 2193.654 & \\
HAC variance & 725.8439 & \\
\hline
\end{tabular}

So from the two methods of co-integration (Pedroni Residual Co-integration Test, Kao Residual Co-integration Test) reveals that the variables are cointegrate.

In the first column of the Table 7 here presented the GLS estimates. The impacts of all the variables under the economic freedom are positive and significant. In the case of business freedom the coefficient implies that a one standard deviation improvement in business freedom increases FDI by $8.36 \%$. 
Table 7. Generalized least square and feasible generalized least square method

\begin{tabular}{|c|c|c|}
\hline Independent Variables & GLS & FGLS \\
\hline & $0.1034 * *$ & $0.1237^{* *}$ \\
\hline \multirow[t]{2}{*}{ GDPPC } & $(0.205)$ & $(0.235)$ \\
\hline & $0.1092 * *$ & $0.1436 * *$ \\
\hline \multirow[t]{2}{*}{ GDPG } & $(0.209)$ & $(0.325)$ \\
\hline & $0.0836^{*}$ & $0.1209^{*}$ \\
\hline \multirow[t]{2}{*}{ Business Freedom } & $(0.189)$ & $(0.317)$ \\
\hline & $0.0658^{*}$ & $0.1027 *$ \\
\hline \multirow[t]{2}{*}{ Trade Freedom } & $(0.151)$ & $(0.213)$ \\
\hline & $0.0895^{*}$ & $0.1094 *$ \\
\hline \multirow[t]{2}{*}{ Government Size } & $(0.192)$ & $(0.272)$ \\
\hline & $0.0943 * *$ & $0.1242 * *$ \\
\hline \multirow[t]{2}{*}{ Investment Freedom } & $(0.241)$ & $(0.369)$ \\
\hline & $0.0928 * *$ & $0.1345^{* *}$ \\
\hline \multirow[t]{2}{*}{ Property Rights } & $(0.293)$ & $(0.389)$ \\
\hline & $0.0562 *$ & $0.1022 *$ \\
\hline \multirow[t]{2}{*}{ Freedom From Corruption } & $(0.135)$ & $(0.238)$ \\
\hline & $0.0594 *$ & $0.0861^{*}$ \\
\hline \multirow[t]{2}{*}{ Labor Freedom } & $(0.143)$ & $(0.186)$ \\
\hline & $0.0425^{*}$ & 0.0733 \\
\hline \multirow[t]{2}{*}{ Financial Freedom } & $(0.127)$ & $(0.182)$ \\
\hline & $0.0537^{*}$ & $0.0844^{*}$ \\
\hline \multirow[t]{2}{*}{ Fiscal Freedom } & $(0.158)$ & $(0.183)$ \\
\hline & $0.0433^{*}$ & $0.0815^{*}$ \\
\hline \multirow[t]{2}{*}{ Monetary Freedom } & $(0.163)$ & $(0.193)$ \\
\hline & $0.0229 * *$ & $0.564^{* *}$ \\
\hline \multirow[t]{2}{*}{ DEMOC } & $(0.104)$ & $(0.165)$ \\
\hline & $0.0205^{* *}$ & $0.0674 * *$ \\
\hline \multirow[t]{2}{*}{ Political Stability } & $(0.168)$ & $(0.236)$ \\
\hline & 0.8654 & 0.1439 \\
\hline Constant & $(0.542)$ & $(0.982)$ \\
\hline Number of Observation & 768 & 768 \\
\hline Wald chi $2(8)$ & 107.69 & 217.34 \\
\hline Prob > chi 2 & 0.0000 & 0.0000 \\
\hline
\end{tabular}

Other different variables like trade freedom, government size, investment freedom, property rights, freedom from corruption, labor freedom, financial freedom, fiscal freedom and monetary freedom the coefficient implies that a one standard deviation improvement in trade freedom, government size, investment freedom, property rights, freedom from corruption, labor freedom, financial freedom, fiscal freedom and monetary freedom increases FDI by $8.95 \%, 9.43 \%, 9.28 \%, 5.62 \%, 5.94 \%, 4.25 \%, 5.37 \%$ and $4.33 \%$ respectively. For the economic variable, GDPG and GDPPC, the coefficient implies that a one standard deviation improvement in GDPG and GDPPC increases FDI by $10.92 \%$ and $10.34 \%$ respectively.

In the Second column of the table presented the FGLS estimates. The impacts of all the variables under the economic freedom are positive and significant. Here all the variables under the economic freedom like business freedom, trade freedom, government size, investment freedom, property rights, freedom from corruption, labor freedom, financial freedom, fiscal freedom, and monetary freedom the coefficient implies that a one standard deviation improvement in business freedom, trade freedom, government size, investment freedom, property rights, freedom from corruption, labor freedom, financial freedom, fiscal freedom and monetary freedom increases FDI by $12.09 \%, 10.27 \%, 10.94 \%, 12.42 \%, 13.45 \%, 10.22 \%, 8.61 \%, 7.33 \%, 8.44 \%$ and $8.25 \%$ respectively, it means that the value is slightly higher from the GLS. Economic variable, GDPG and GDPPC, the coefficient implies that a one standard deviation improvement in GDPG and GDPPC increases FDI by $14.36 \%$ and $12.37 \%$ respectively. 
Table 8. Pooled OLS

\begin{tabular}{|c|c|c|c|c|c|c|c|c|c|c|c|c|c|}
\hline Estimation Metl & thod & & & & & & POOLED & D OLS & & & & & \\
\hline Independent & & & & & & & & & & & & & \\
\hline Variable & & 1 & 2 & 4 & 5 & 6 & & 7 & 8 & 10 & 11 & & 12 \\
\hline & 0.291 & & & & & & & & & & & & \\
\hline GDPPC & $(2.101)^{*}$ & & & & & & & & & & & & \\
\hline & & 0.378 & & & & & & & & & & & \\
\hline GDPG & & $(1.051)^{* *}$ & & & & & & & & & & & \\
\hline Business & & & 0.245 & & & & & & & & & & \\
\hline Freedom & & & $(0.005)^{*}$ & & & & & & & & & & \\
\hline Trade & & & & 0.373 & & & & & & & & & \\
\hline Freedom & & & & $(2.184)^{* *}$ & & & & & & & & & \\
\hline Government & & & & & 0.263 & & & & & & & & \\
\hline Size & & & & & $(0.542)^{* *}$ & & & & & & & & \\
\hline Investment & & & & & & 0.145 & & & & & & & \\
\hline Freedom & & & & & & $(1.183)^{* *}$ & & & & & & & \\
\hline Property & & & & & & & 0.229 & & & & & & \\
\hline Rights & & & & & & & $(1.026)^{* *}$ & & & & & & \\
\hline Freedom From & & & & & & & & 0.115 & & & & & \\
\hline Corruption & & & & & & & & $(1.174)^{* * *}$ & & & & & \\
\hline Labor & & & & & & & & & 0.319 & & & & \\
\hline Freedom & & & & & & & & & $(1.178)^{* * *}$ & & & & \\
\hline Financial & & & & & & & & & & 0.327 & & & \\
\hline Freedom & & & & & & & & & & $(1.025)^{* *}$ & & & \\
\hline Fiscal & & & & & & & & & & & 0.329 & & \\
\hline Freedom & & & & & & & & & & & $(1.275)^{* * *}$ & & \\
\hline Monetary & & & & & & & & & & & & 0.245 & \\
\hline Freedom & & & & & & & & & & & & $(2.153)^{* * *}$ & \\
\hline & 0.943 & 0.846 & 0.925 & 0.739 & 0.833 & 0.916 & 0.963 & 0.910 & 0.817 & 0.859 & 0.960 & 0.883 & \\
\hline DEMOC & $(2.049)^{* *}$ & $(1.916)^{* *}$ & $(1.531)^{* *}$ & $(1.148)^{* *}$ & $(1.138)^{* *}$ & $(2.163)^{* *}$ & $(2.293)^{* *}$ & $(1.573)^{* *}$ & $(1.119)^{* *}$ & $(1.726)^{* *}$ & $(2.575)^{* *}$ & $(1.945)^{* *}$ & \\
\hline Political & 1.131 & 1.161 & 1.121 & 1.312 & 1.211 & 1.113 & 1.143 & 1.192 & 1.123 & 1.132 & 1.134 & 1.336 & \\
\hline Stability & $(0.101)^{*}$ & $(0.100)^{*}$ & $(0.101)^{*}$ & $(0.101)^{*}$ & $(0.103) *$ & $(0.104)^{*}$ & $(0.103) *$ & $(0.111)^{*}$ & $(0.119)^{*}$ & $(0.109)^{*}$ & $(0.119)^{*}$ & $(0.124)^{*}$ & \\
\hline
\end{tabular}

From the Pooled OLS method, the impact of all the variables under the economic freedom has also explored to be positive and significant. In the case of business freedom the coefficient implies that a one standard deviation improvement in business freedom increases FDI by $24.5 \%$. The coefficient of trade freedom implies that a one standard deviation improvement in business freedom increase FDI by $37.3 \%$. Another variable under the economic freedom the coefficient of government size implies that a one standard deviation improvement in government size increase FDI by $26.3 \%$. In the case of investment freedom the coefficient implies that a one standard deviation improvement in investment freedom increases FDI by $14.5 \%$. On the concentration of the property rights the coefficient implies that a one standard deviation improvement in property rights increases FDI by $22.4 \%$. The coefficient of freedom from corruption implies that a one standard deviation improvement in freedom from corruption increases FDI by $11.5 \%$. In the case of labor freedom the coefficient implies that a one standard deviation improvement in business freedom increases FDI by $31.9 \%$. In the case of financial freedom the coefficient implies that a one standard deviation improvement in financial freedom increases FDI by $32.7 \%$. The coefficient of fiscal freedom implies that a one standard deviation improvement in fiscal freedom increases FDI by $32.4 \%$. In the case of monetary freedom the coefficient implies that a one standard deviation improvement in monetary freedom increases FDI by $24.5 \%$. Economic variable like GDPG and GDPPC, the coefficient implies that a one standard deviation improvement in GDPG and GDPPC increases FDI by $37.8 \%$ and $29.1 \%$ respectively.

According to the OLS estimates from the Table 9, the impact of all the variables under the economic freedom are positive and significant. In the case of business freedom the coefficient implies that a one standard deviation improvement in business freedom increases FDI by $21.4 \%$. On the concentration of the trade freedom, the coefficient implies that a one standard deviation improvement in trade freedom increases FDI by $15.6 \%$. Other different variables like government size, investment freedom, property rights, freedom from corruption, labor 
freedom, financial freedom, fiscal freedom and monetary freedom the coefficient implies that a one standard deviation improvement in size, investment freedom, property rights, freedom from corruption, labor freedom, financial freedom, fiscal freedom and monetary freedom increases FDI by $21.6 \%, 17.5 \%, 11.5 \%, 9.1 \%, 6.9 \%$, $8.5 \%, 7.4 \%$ and $10.3 \%$ respectively. For the economic variable, GDPG and GDPPC, the coefficient implies that a one standard deviation improvement in GDPG and GDPPC increases FDI by $24.1 \%$ and $17.4 \%$ respectively.

From the second column of the table 9 the paper present the random effect estimates. The impacts of all the variables under the economic freedom are also found positive and significant. In the case of business freedom the coefficient implies that a one standard deviation improvement in business freedom increases FDI by $37.3 \%$ which is slightly higher from than in the case of OLS. On the other hand in the case of the trade freedom, the coefficient implies that a one standard deviation improvement in trade freedom increases FDI by $12.9 \%$. Other different variables like government size, investment freedom, property rights, freedom from corruption, financial freedom and monetary freedom the coefficient implies that a one standard deviation improvement in government size, investment freedom, property rights, freedom from corruption, financial freedom and monetary freedom increases FDI by $16.3 \% 12.2 \%, 10.5 \%, 7.5 \%, 5.4 \%$ and $9.3 \%$ which is slightly lower from than in the case of OLS. On the other hand labor Freedom and Fiscal Freedom the coefficient implies that a one standard deviation improvement in labor freedom and fiscal freedom increases FDI by $7.2 \%$ and $8.5 \%$ which is slightly higher than OLS. Economic variable like GDPG and GDPPC, the coefficient implies that a one standard deviation improvement in GDPG and GDPPC increases FDI by $25.3 \%$ and $35.9 \%$ respectively.

Table 9. Panel data estimates

\begin{tabular}{|c|c|c|c|c|c|c|c|}
\hline Estimation & 1 & 2 & 3 & 4 & 5 & 6 & 7 \\
\hline Method & OLS & Random Effect & Fixed effect & Poisson Regression & Prais-Winsten & GMM & GEE \\
\hline \multicolumn{8}{|c|}{ Log Dependent Variables } \\
\hline & 0.174 & 0.359 & 0.182 & 0.112 & 0.215 & 0.261 & 0.339 \\
\hline \multirow[t]{2}{*}{ GDPPC } & $(21.453)^{* * *}$ & $(17.091)^{* * *}$ & $(25.291)^{* * *}$ & $(23.194)^{* * *}$ & $(19.052)^{* * *}$ & $(28.959) * * *$ & $(29.816)^{* * *}$ \\
\hline & 0.241 & 0.253 & 0.356 & 0.417 & 0.267 & 0.358 & 0.302 \\
\hline GDPG & $(13.396)^{* * *}$ & $(15.854)^{* * *}$ & $(23.182)^{* * * *}$ & $(19.904)^{* * * *}$ & $(17.239)^{* * * *}$ & $(23.941)^{* * *}$ & $(26.032)^{* * * *}$ \\
\hline Business & 0.214 & 0.373 & 0.454 & 0.414 & 0.368 & 0.547 & 0.561 \\
\hline \multirow[t]{2}{*}{ Freedom } & $(1.673)^{* *}$ & $(1.845)^{* *}$ & $(2.166)^{* *}$ & $(2.031)^{* *}$ & $(1.828)^{* *}$ & $(2.161)^{* *}$ & $(3.102)^{* *}$ \\
\hline & 0.156 & 0.129 & 0.378 & 0.283 & 0.237 & 0.348 & 0.453 \\
\hline Trade Freedom & $(1.241)^{* *}$ & $(1.041)^{* *}$ & $(2.158)^{* *}$ & $(2.025)^{* *}$ & $(2.144)^{* *}$ & $(2.612)^{* *}$ & $(2.947)^{* *}$ \\
\hline Government & 0.216 & 0.163 & 0.406 & 0.352 & 0.368 & 0.451 & 0.583 \\
\hline Size & $(1.153)^{* *}$ & $(1.117)^{* *}$ & $(2.946)^{* *}$ & $(2.146)^{* *}$ & $(2.379)^{* *}$ & $(3.348)^{* *}$ & $(3.472)^{* *}$ \\
\hline Investment & 0.175 & 0.122 & 0.364 & 0.233 & 0.326 & 0.293 & 0.516 \\
\hline Freedom & $(1.063)^{* *}$ & $(1.114)^{* *}$ & $(2.351)^{* *}$ & $(2.151)^{* *}$ & $(2.316)^{* *}$ & $(2.346)^{* *}$ & $(3.463)^{* *}$ \\
\hline Property & 0.115 & 0.105 & 0.269 & 0.176 & 0.228 & 0.284 & 0.337 \\
\hline Rights & $(1.091)^{* *}$ & (1.120) & $(2.465)^{* *}$ & $(1.672)^{* *}$ & $(1.859)^{* *}$ & $(2.152)^{* *}$ & $(2.859)^{* *}$ \\
\hline Freedom From & 0.091 & 0.075 & 0.294 & 0.157 & 0.215 & 0.314 & 0.392 \\
\hline \multirow[t]{2}{*}{ Corruption } & $(0.762)^{* *}$ & $(0.631)^{* *}$ & $(2.653)^{* *}$ & $(1.459)^{* *}$ & $(1.941)^{* *}$ & $(2.964)^{* *}$ & $(3.288)^{* *}$ \\
\hline & 0.069 & 0.072 & 0.184 & 0.259 & 0.229 & 0.352 & 0.474 \\
\hline Labor Freedom & $(0.529)^{* *}$ & $(0.458)^{* *}$ & $(1.157)^{* *}$ & $(2.117)^{* *}$ & $(2.021)^{* *}$ & $(3.157)^{* *}$ & $(4.571)^{* *}$ \\
\hline Financial & 0.085 & 0.054 & 0.174 & 0.214 & 0.317 & 0.259 & 0.416 \\
\hline \multirow[t]{2}{*}{ Freedom } & $(0.624)^{* *}$ & $(0.439)$ & $(1.260)^{* *}$ & $(2.014)^{* *}$ & $(2.962)^{* *}$ & $(2.273)^{* *}$ & $(4.293)^{* *}$ \\
\hline & 0.074 & 0.085 & 0.218 & 0.236 & 0.219 & 0.284 & 0.325 \\
\hline Fiscal Freedom & $(0.593)^{* *}$ & $(0.715)^{* *}$ & $(2.127)^{* *}$ & $(2.194)^{* *}$ & $(2.128)^{* *} *$ & $(2.393)^{* *}$ & $(3.102)^{* *}$ \\
\hline Monetary & 0.103 & 0.093 & 0.182 & 0.282 & 0.211 & 0.313 & 0.385 \\
\hline \multirow[t]{2}{*}{ Freedom } & $(0.815)^{* *}$ & $(0.742)^{* *}$ & $(1.528)^{* *}$ & $(2.417)^{* *}$ & $(2.146)^{* *}$ & $(0.283)^{* *}$ & $(0.337)^{* *}$ \\
\hline & 0.091 & 0.074 & 0.058 & 0.841 & 0.942 & 0.108 & 0.138 \\
\hline DEMOC & $(0.642)^{* *}$ & $(0.592)^{* *}$ & $(0.448)^{* *}$ & $(0.758)^{* *}$ & $(0.836)^{* *}$ & $(1.038)^{* *}$ & $(1.295)^{* *}$ \\
\hline Political & 0.294 & 0.366 & 0.682 & 0.793 & 0.851 & 0.106 & 0.148 \\
\hline Stability & $(0.172)^{*}$ & $(0.194)^{*}$ & $(0.394)^{*}$ & $(0.671)^{*}$ & $(0.705)^{*}$ & $(1.025)^{*}$ & $(1.295)^{*}$ \\
\hline
\end{tabular}

According to the fixed effect estimates here are also the impact of all the variables under the economic freedom has also explored to be positive and significant. In the case of business freedom, trade freedom, government size, investment freedom, property rights, freedom from corruption, labor freedom, financial freedom, fiscal freedom and monetary freedom the coefficient implies that a one standard deviation improvement in business freedom, 
trade freedom, government size, investment freedom, property rights, freedom from corruption, labor freedom, financial freedom, fiscal freedom and monetary freedom increases FDI by $45.4 \%, 37.8 \%, 40.6 \%, 36.4 \%, 26.9 \%$, $29.4 \%, 18.9 \%, 17.4 \%, 21.8 \%$ and $18.2 \%$ respectively which is higher than OLS and Random Effect Model. For the economic variable, GDPG and GDPPC, the coefficient implies that a one standard deviation improvement in GDPG and GDPPC increases FDI by $35.6 \%$ and $18.2 \%$ respectively.

From the fourth column of the table presented the Poisson Regression estimates. Here also the impacts of all the variables under the economic freedom are explored to be positive and significant. In the case of business freedom, trade freedom, government size, investment freedom, property rights, freedom from corruption the coefficient implies that a one standard deviation improvement in business freedom, trade freedom, government size, investment freedom, property rights and freedom from corruption increases FDI by $41.4 \%, 28.3 \%, 35.2 \%$, $23.3 \%, 17.6 \%, 15.7 \%$ respectively which is slightly lower than in the case of OLS, Random Effect Model and Fixed Effect Model. On the other hand the other variables like labor freedom, financial freedom, fiscal freedom and monetary freedom the coefficient implies that a one standard deviation improvement in labor freedom, financial freedom, fiscal freedom and monetary freedom increases FDI by $25.9 \%, 21.4 \%, 23.6 \%$ and $28.2 \%$ respectively and which is slightly higher than Fixed Effect Model. For the economic variable, GDPG and GDPPC, the coefficient implies that a one standard deviation improvement in GDPG and GDPPC increases FDI by $41.7 \%$ and $11.2 \%$ respectively.

From the fifth column according to the Prais-Winsten estimates, here all the variables under the economic freedom are explored to be positive and significant. In the case of business freedom, trade freedom, labor Freedom, fiscal Freedom and monetary freedom the coefficient implies that a one standard deviation improvement in business freedom, trade freedom, labor Freedom, fiscal freedom and monetary freedom increases FDI by $36.8 \%, 23.7 \%, 22.9 \%, 21.9 \%$ and $21.1 \%$ respectively and that is lower value from the Poisson Regression. On the other hand government size, investment freedom, property rights, freedom from corruption and fiscal freedom the coefficient implies that a one standard deviation improvement in government size, investment freedom, property rights, freedom from corruption and fiscal freedom increases FDI by $36.8 \%$, $32.6 \%, 22.8 \%, 21.5 \%$ and $31.7 \%$ respectively which is higher value from the Poisson Regression. Economic variable like GDPG and GDPPC, the coefficient implies that a one standard deviation improvement in GDPG and GDPPC increases FDI by $26.7 \%$ and $21.5 \%$ respectively.

From the sixth column of the table concentrates on the GMM estimates, here noted that all the variables under the economic freedom are also explored to be positive and significant. In the case of business freedom, trade freedom, government Size, property rights, freedom from corruption, labor freedom, fiscal freedom and monetary freedom the coefficient implies that a one standard deviation improvement in business freedom, trade freedom, government Size, property rights, freedom from corruption, labor freedom, fiscal freedom and monetary freedom increases FDI by $54.7 \%, 34.8 \%, 45.1 \%, 28.4 \%, 31.4 \%, 35.2 \%, 28.4 \%$ and $31.3 \%$ respectively which implies that is slightly higher from the Prais-Winsten estimates. On the other hand the other variables from the economic freedom like investment freedom and financial freedom the coefficient implies that a one standard deviation improvement in investment freedom and financial freedom increases FDI by $29.3 \%$ and $25.4 \%$ respectively and that is slightly lower from the previous estimates. Economic variable like GDPG and GDPPC, the coefficient implies that a one standard deviation improvement in GDPG and GDPPC increases FDI by 35.8\% and $26.1 \%$ respectively.

From the seven column of the table has presented the GEE estimates. All the variables under the economic freedom are also explored to be positive and significant. In the case of business freedom, trade freedom, government size, investment freedom, property rights, freedom from corruption, labor freedom, financial freedom, fiscal freedom and monetary freedom the coefficient implies that a one standard deviation improvement in business freedom, trade freedom, government Size, investment freedom, property rights, freedom from corruption, labor freedom, financial freedom, fiscal freedom and monetary freedom increases FDI by $56.1 \%, 45.3 \%, 58.3 \%, 51.6 \%, 33.7 \%, 39.2 \%, 47.4 \%, 41.6 \%, 32.5 \%$ and $38.5 \%$ respectively. Economic variable like GDPG and GDPPC, the coefficient implies that a one standard deviation improvement in GDPG and GDPPC increases FDI by $30.2 \%$ and $33.4 \%$ respectively.

\section{Conclusion}

This paper has examined the relations among economic freedom, FDI and economic growth in the developing country. It finds that there are positive relations among economic freedom, FDI and economic growth. Economic freedom is a significant determinants of foreign direct investment because of unremitting flow of investment it helps to enhance the competitiveness of the economic outlooks. Due to the economic freedom, the foreign 
entrepreneurs are accumulates substantial amount of confidence to make investment in the host countries and that consequence on enhancing the economic growth. It is true that not always economic freedom stimulates FDI; there are also some inevitable factors that may consider the different MNC's to make investment in the host countries especially in developing countries. Investment in the host countries may depends on the market size, economic growth, financial development, macroeconomic stability, geographical distance and many more. Above all host countries governments should ensure to achieve a sound degree of political and economic stability, along with a market-oriented environment that really assists for proliferating economic growth in the developing countries.

\section{References}

Adkins, L. C., Ronald, L. M., \& Andreas, S. (2002). Institutions, freedom, and technical efficiency. Southern Economic Journal, 69(7), 92-108. http://dx.doi.org/10.2307/1061558

Ajide, K. B. (2013). Economic freedom, foreign direct investment and growth: Empirical evidence from Nigeria. International Journal of Economic, 6(2), 143-58.

Asiedu, E. (2002). On the determinants of foreign direct investment to developing Countries: Is Africa different? World Development, 30(1), 107-119. http://dx.doi.org/10.1016/S0305-750X(01)00100-0

Asiedu, E. (2006). Foreign direct investment in Africa: The role of government policy, institutions and political instability. World Economy, 29(1), 63-77. http://dx.doi.org/10.1111/j.1467-9701.2006.00758.x

Ayal, B. E., \& Karras, G. (1998). Components of economic freedom and growth: An Empirical Study. Journal of Developing Areas, 32(3), 327-38.

Azman-Saini,W. N., Baharumshah, A. Z., \& Law, S. H. (2010). Foreign direct investment, economic freedom and economic growth: International Evidence. Economic Modelling, 27(5), 1079-89. http://dx.doi.org/10.1016/j.econmod.2010.04.001

Barro, R. J. (1997). Determinants of economic growth: A cross country empirical study. Cambridge: The MIT Press.

Barro, R. J. (2000). Rules of law, democracy, and economic performance. In G. P. O’ Driscoll, K. R. Holmes, and M. Krikapatrick (Eds.), 2000 Index of Economic Freedom. Heritage Foundation and the Wall Street Journal, Washington DC and New York.

Bengoa, M., \& Sanchez-Robles. (2003). FDI, economic freedom, and growth: New evidence from Latin America. European Journal of Political Economy, 19, 529-545. http://dx.doi.org/10.1016/S0176-2680(03)00011-9

Cebula, R., \& Mixon, F. (2012). The Impact of fiscal and other economic freedoms on economic growth: An Empirical Analysis. International Advances in Economic Research, 18(2), 139-50. http://dx.doi.org/10.1007/s11294-012-9348-1

Chakrabarti, A. (2001). The determinants of foreign direct investment: Sensitivity analyses of cross-country regressions. Kyklos, 54, 89-113. http://dx.doi.org/10.1111/1467-6435.00142

Compton, R. A., Giedeman, D. C., \& Hoover, G. A. (2011). Panel evidence on economic freedom and growth in the United States. European Journal of Political Economy, 27, 423-435. http://dx.doi.org/10.1016/j.ejpoleco.2011.01.001

Dawson, J. W. (1998). Institutions, investment, and growth: New cross-country and panel data evidence. Economic Inquiry, 36(4), 603-620. http://dx.doi.org/10.1111/j.1465-7295.1998.tb01739.x

De Hann, J., Lundstrom, S., \& Sturm, J. (2006). Market-oriented institutions and policies and economic growth: A Critical Survey. Journal of Economic Surveys, 20, 157-91. http://dx.doi.org/10.1111/j.0950-0804.2006.00278.x

Dunning, J. H. (1993). Multinational enterprises and the global economy. Wokingham: Addision-Wesley.

Durham, J. B. (2004). Absorptive capacity and the effects of foreign direct investment and equity foreign portfolio investment on economic growth. European Economic Review, 48, 285-306. http://dx.doi.org/10.1016/S0014-2921(02)00264-7

Dutta, N., \& Osei-Yeboah, K. (2010). Foreign direct investment and human capital: The role of political and civil rights. Journal of International Development, Forthcoming. Retrieved from http://ssrn.com/abstract=1263038

Estrin, S., Bevan, A., \& Meyer, K. (2001). Institution building and the integration of Eastern Europe in 
international production. Working Paper 16/01, Centre for New \& Emerging Markets.

Ghura, D., \& Goodwin, B. (2000). Determinants of private investment: A cross-regional empirical investigation. Applied Economics, 32(14), 1819-1835. http://dx.doi.org/10.1080/000368400425044

Globerman, S., \& Daniel, S. (2003). Governance infrastructure and US foreign direct investment. Journal of International Business Studies, 34, 19-39. http://dx.doi.org/10.1057/palgrave.jibs.8400001

Gwartney, J. (2009). Institutions, economic Freedom and cross-country differences in performance. Southern Economic Journal, 75(4), 937-956.

Hansen, H., \& Rand, J. (2006). On the causal links between FDI and growth in developing countries. The World Economy, 29(1), 21-41. http://dx.doi.org/10.1111/j.1467-9701.2006.00756.x

Heckelman, J. C. (2000). Economic freedom and economic growth: A short-run causal investigation. Journal of Applied Economics, 3(1), 71-91.

Levina, O. (2011). FDI, economic freedom and growth. Are they related? Being an unpublished MA, Department of Economics, Central European University.

Mlambo, K. (2006). Reviving foreign direct investments in Southern Africa: Constraints and Policies. African Development Review, 17(3), 552-579. http://dx.doi.org/10.1111/j.1017-6772.2006.00128.x

Onyeiwu, S., \& Shrestha, H. (2004). Determinants of foreign direct investment in Africa. Journal of Developing Societies, 20, 89-106. http://dx.doi.org/10.1177/0169796X04048305

Zhao, H. (2013). Technology imports and their impacts on the enhancement of China's indigenous technological capability. Journal of Development Studies, 31(4), 585-602. http://dx.doi.org/10.1080/00220389508422379

\section{Copyrights}

Copyright for this article is retained by the author(s), with first publication rights granted to the journal.

This is an open-access article distributed under the terms and conditions of the Creative Commons Attribution license (http://creativecommons.org/licenses/by/4.0/). 